\title{
Nutrition Education 4.0 to Prevent Overweight and Obesity Through Webinar: A Research Protocol
}

Trias Mahmudiono ${ }^{1 *} \mathbb{D}$, Dominikus Raditya Atmaka ${ }^{1}$, Su Peng Loh ${ }^{3} \mathbb{D}$, Qonita Rachmah ${ }^{1}$ D, Mahmudah Mahmudah ${ }^{2}$,

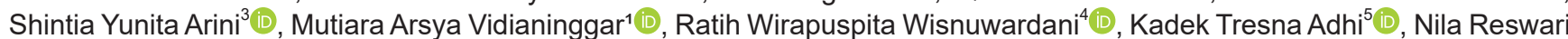
Haryana $^{6}$ (D), Setyo Utami Wisnusanti ${ }^{7}$, Windi Indah ${ }^{8}$ id, Nikmah Utami Dewi ${ }^{9}$ (D)

${ }^{1}$ Department of Nutrition, Faculty of Public Health, Universitas Airlangga, Surabaya, Indonesia; ${ }^{2}$ Department of Epidemiology, Biostatistics, and Health Promotion, Faculty of Public Health, Universitas Airlangga, Surabaya, Indonesia; ${ }^{3}$ Department of Occupational Health and Safety, Faculty of Public Health, Universitas Airlangga, Surabaya, Indonesia; ${ }^{4}$ Department of Public Health, Faculty of Public Health, Universitas Mulawarman, Samarinda, Indonesia; ${ }^{5}$ Department of Public Health, Faculty of Medicine, Universitas Udayana, Kuta Selatan, Indonesia; ${ }^{6}$ Department of Nutrition, Faculty of Public Health, Universitas Negeri Medan, Medan, Indonesia; ${ }^{7}$ Department of Nutrition, Faculty of Medicine, Public Health and Nursing, Universitas Gadjah Mada, Yogyakarta, Indonesia; ${ }^{8}$ Department of Nutrition, Faculty of Public Health, Universitas Sriwijaya, Palembang, Indonesia; ${ }^{9}$ Department of Nutrition, Faculty of Public Health, Universitas Tadulako, Palu, Indonesia

Edited by: Sasho Stolesk Citation: Mahmudiono T, Atmaka DR, Loh SP, Rachmah Q, Mahmudah M, Arini SY, Vidianinggar MA Wisnuwardani RW, Adhi KT, Haryana NR, Wisnusanti SU, Indah W, Dewi NU. Nutrition Education 4.0 to Preven Overweight and Obesity Through Webinar: A Research 10(E):92-96. https://doi.org/10.3889/oamims.2022.7412 Keywords: Online; Nutrition education; Obesity; Adults; Health and well-being *Correspondence: Trias Mahmudiono, Department of Nutrition, Faculty of Public Health, Universitas Airlangga, Indonesia. E-mail: trias-m@fkm.unair.ac.id Received: 05-Dec-202 Revised: 12-Dec-2021 Copyright: 82022 Tria $M-D e c-2021$ Copyright: $\odot 2022$ Tras Mahmudiono,

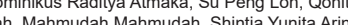
Mutiara Arsya Vidianinggar, Ratih Wirapuspita Wisnuwardani, Kadek Tresna Adhi, Nila Reswari Haryana Setyo Utami Wisnusanti, Windi Indah, Nikmah Utami Dew Funding: This research did not receive any financia Competing Interests: The authors have declared that no competing interests exist Open Access: This is an open-access article distributed under the terms of the Crealive Commons Attribution-

\begin{abstract}
The COVID-19 pandemic in Indonesia has made changes in the learning system from face-to-face learning to online learning. With these conditions, technology should be utilized by making an innovation to improve the quality of learning. In this regard, innovations that can be done include the implementation of website seminar activities (webinar) in the midst of a pandemic. Webinars are a learning resource that can be widely accessed by students academics, and the general public. Of course, this webinar activity is very useful to increase knowledge and insight. The prevalence of obesity in Indonesia according to Riskesdas 2018 shows that $13.6 \%$ of adults aged $>18$ years are overweight while $21.8 \%$ are obese. One of the challenges in this phase of life is how to influence and encourage young adults to adopt healthy eating behaviors. Therefore, one way that can be done to increase knowledge, attitudes, and behavior toward eating habits is to provide nutrition education through social media. This study aims to increase knowledge, attitudes, and behavior toward the habit of ordering food online, nutrient-dense food and energy-dense food, food safety, physical activity, sugar-sweetened beverage, and intake of energy, protein, fat, and fiber through the platform. Social media is widely used by the target. This is a randomized control trial study by giving nutrition education intervention related to reduction of obesity in adults age 17-25 years. This study targets adults using a quasi-experiment design with a pre- and post-test control group design. The study will be conducted online in Indonesia. A total of 311 adults aged 17-25 years are joining in this research.
\end{abstract}

\section{Highlights}

- Online nutrition education intervention

- $\quad$ Protocol and curriculum nutrition education to reduce obesity in adults

- Relevant with SDGs three to improve the health and well-being of adults in Indonesia.

\section{Introduction}

\section{Background}

The COVID-19 pandemic in Indonesia has made changes in the learning system from face-to-face learning to online learning. Since the COVID-19 case in Indonesia, the government has implemented a policy of studying and working from home since mid-March 2020. The COVID-19 pandemic with the implementation of distance learning has changed the learning process in the classroom. Under these conditions, technology should be utilized by making an innovation to improve the quality of learning. Along with the development of technology, the world of education must make positive innovations for the advancement of education [1].

Related to this, positive innovations that can be done include the implementation of website seminar activities (webinars) in the midst of a pandemic. Webinars are a learning resource that can be widely accessed by students, academics, and the general public. Of course, this webinar activity is very useful 
to increase knowledge and insight related to webinar material. With the webinar as distance learning, where teaching and learning without face-to-face directly between participants who are given the material with the presenters/resource persons. Since webinar can be considered as a learning process which can be done from distance the teacher/presenter still can give their material clearly through video conference or upload it through social media platform. The learning process/ lectures through webinars have been widely used by various educational institutions/institutions as a form of utilizing information technology in the midst of the COVID-19 pandemic. To conduct distance learning activities through webinars, a good internet connection is needed. Webinars are held in the form of presentations, lectures, workshops, or seminars conducted through a web interface (Putra AE. 2018).

Online nutrition education is one of the alternatives that can be implemented if the face-toface nutrition education is not available. Face-to-face intervention is delivered both in the form of individual intervention and group intervention. However this method has a limitation related to the reach of individual who have time constrains or stay in a different physical location. On the other side, online intervention can be applied to the targeted population with less limitation, because online platform can be used by anyone at anytime and anywhere.

Online learning programs in nutrition education have potential to accommodate synchronized form of communication between speaker and learner. It is not only accommodate the speaker and learner but it is also give the learner chance to share about each other's thought though synchronized video conference. Nutrition education which is done by using online platform can target a wider scope of population. It has proven that nutrition education through online platform can increase the awareness among parents indicated by the food availability is increasing along with food choices which has changed into $100 \%$ fruit and vegetable juice and decreasing amount of fatty food consumption. (Cullen, et al. 2017) [19]

Obesity is one of the nutritional problems that are increasing from year to year in Indonesia. The prevalence of obesity in Indonesia according to Riskesdas 2018 shows that $13.6 \%$ of adults aged $>18$ years are overweight while $21.8 \%$ are obese [3]. Several comorbidities related to overweight and obesity include cancer, type 2 diabetes mellitus, hypertension, stroke, coronary heart disease, and other non-communicable diseases later (Minister of Health Republic Indonesia RISKESDAS, 2018).

Since obesity is one of health issues faced by many people in this world, some protocol and practical guidelines to treat obesity have been published by National Heart Lung and Blood Institute North America Association for The Study Obesity in 2000. The therapies that can be done are by reducing the amount of calorie intake by 500 to $1000 \mathrm{kcal}$ per day from the current level assessed from nutrient intake. Beside reducing the amount of calorie intake, it was mentioned that physical activities is an important thing that has to be done to achieve ideal body weight. All adults are recommended to set a long-term goal to accumulate at least 30 minutes or more of moderate-intensity physical activity on most days at one week and preferably one week straight. Behavioral therapy also has to be conducted to adjunct the adjustment in food and physical activity. All of the life style changes previously mentioned can be combined with pharmacotherapy intervention for individual who has had a severe obesity. All of those intervention as mentioned before can be controlled through online consultation and combine it with offline assessment. (NHLBI, 2000)

Young adults are a stage where there is a life transition from adolescence, increasing independence, and increasing autonomy in food choices, physical activity, and the development of cooking skills. One of the challenges in this phase of life is how to influence and persuade young adults to adopt healthy eating behaviors [2]. The high use of social media platforms allows young adults to get a lot of information about nutrition and health from social media. Therefore, one way that can be done to increase knowledge, attitudes, and behavior toward eating habits is to provide nutrition education through webinars ( Klassen KM, et al. 2018).

This research roadmap is in line with the pillars of public health, namely health promotion (Health Promotion) and public health nutrition (Public Health Nutrition) to improve public health status. The development of research on public health nutrition is directed at the healthy-riskproblem range of nutrition. The form of nutritional problems in this study is over nutrition which consists of overweight and obesity problems. The main focus in research on over nutrition is how to make adolescents and young adults know, want, and are able to improve their own health status and prevent overweight and obesity. It is also aimed to increase adult health which will accumulatively increase Indonesia involvement to achieve SDGs 3, which is to ensure a healthy life and promote wealth to all layers of the community. Providing education through a platform that is close to adolescents and young adults is expected to increase knowledge, attitudes, and behavior in preventing overweight and obesity.

\section{Study objective}

The aims of the study are to determine the effectiveness of webinar nutrition education related to reduction of obesity in adults age 17-25 years.

The primary objective is to improve knowledge, attitudes, and behavior toward the habit of ordering food online, nutrient-dense food and energy-dense food, food safety, physical activity, sugar-sweetened beverage, as well as intake of energy, protein, fat, and fiber through many social media platforms used by the target. Primary 
Hypothesis: webinar nutrition education associated with the reduction of obesity and health well-being in adults.

\section{Secondary objective}

Adult's nutrition knowledge and attitude

1. Determine adult's nutrition knowledge related to reduction of obesity

2. Determine adult's attitude toward food preference and health well-being

3. Determine the physical activity and intake changes on adulthood during the COVID-19 pandemic.

\section{Adult's knowledge change}

Measure delta knowledge change (total change), comparing both post- and pre-test to control measured before and after webinar nutrition education.

\section{Methods}

\section{Study design}

This is a randomized control trial study by giving webinar nutrition education intervention related to obesity. This study targets adults with a pre- and post-test design. Our team have been randomized the population to two different group, which are intervention group and controlled group. These groups are divided by age, gender, and education. Each group has received a properly distributed population and we try to maintain our participants for joining the webinar until finish.

\section{Participant selection and enrolment}

\section{Identifying and selecting participant}

Subjects are part of a population that can be determined in a number using certain means and existing considerations. One way to calculate the number of subjects was to use the Slovin formula (1960), as follows:

$$
\begin{aligned}
& n=\frac{N}{1+N e^{2}} \\
& n=\frac{1190}{1+\left[1190 \times(0.05)^{2}\right.} \\
& n=\frac{1190}{1+[1190 \times(0.0025)]} \\
& n=\frac{1190}{3.975} \\
& n=299.37 \approx 300 \text { adults }
\end{aligned}
$$

$\mathrm{n}$ = sample size

$\mathrm{N}=$ population size

e = Fault tolerance limit (0.05)

Based on the calculations using the Slovin formula, for 1 research in adulthood minimum sample needed as many as 300 adults who were registered in webinar nutrition education. Hence, all of the adults in Indonesia visible to join this webinar nutrition education, the total sample needed is as many as 311 adults aged 17-25 years.

\section{Consenting participant}

The participants will be informed about the purpose of the study, the procedures involved when participating, and asked for their consent. Informed consent will be in Indonesian, and it also explains briefly about the study, purpose, duration, as well as rights and obligations of respondents. It will be explained to the participants is voluntary and the respondent will be educated particularly by researchers. Participants will receive informed consent through online survey application.

\section{Recruitment of participants}

Due to the COVID-19 pandemic situation, offline recruitment is not possible, so it must be carried out online. The research team conducted several promotions with social media strategy. Through this webinar, it is expected that the aspirations, creativity, and innovation of speakers in delivering nutrition and health education materials to students can be delivered properly. The big theme of this competition is "Webinar Nutrition Education 4.0 to Reduce Obesity in Adults."

\section{Study site}

\section{Setting and number of participant}

The study will be conducted online through Zoom Meeting/Microsoft Teams in many urban areas (center) in Indonesia. A total of webinar respondents nutrition education 4.0 are 311 adults aged 17-25 years.

\section{Inclusion criteria}

Adult will be included if they meet all the following inclusion criteria:

1. 17-25 years of age

2. Study in adults in Indonesia

3. Intending to follow the webinar nutrition education 4.0

4. Have smartphone and online platform meeting: Zoom meeting. 


\section{Exclusion criteria} education 4.0.

Adults who did not register for webinar nutrition

\section{Data collection and statistical analysis}

Data will be collected through a pre- and posttest questionnaire and given to all participants online. All available data will be analyzed descriptively. Results will be summarized as frequencies and percentages for nominal data. Bivariate analysis was done using the t-paired test with a nominal data scale. Results for bivariate analysis will be summarized as p-value and cross-tabulation table. The results from the bivariate analysis will be summarized as p-value, odds ratio, and 95\%-confidence interval. The normality test was analyzed using the Kolmogorov-Smirnov test. To analyze the effectiveness of online nutrition education, all the statistical analyses before will be performed using IBM SPSS 25 software.

We try to analyze changes in knowledge by observing the escalation of score before and after webinar. We also have a personal chat with our related participants and ask for a suggestion for our webinar and materials given in the form of modules. Some of our participant experience that our webinar and modules has reached out their heart and they started to have an intention to start a better life with a better pattern of eating. Unfortunately, we haven't made any quantitative tools to analyze it, so until now we haven't able to give a further examination related to our participant's changes specifically related to behavior changes. We only examine the changes in knowledge which validated by the escalation of the score from pre- to post-test.

\section{Intervention}

\section{Intervention allocation}

The respondents from various universities in Indonesia deliver intervention by webinar nutrition education 4.0 with topic obesity. As for further steps, participants will be contacted by the researcher to fill online survey application (pre- and post-test) through webinar's topic.

All participants will be given the written material through webinar the Center for Health and Nutrition Education, Counseling and Empowerment (CHeNECE) Research Group's website and can be accessed from https://chenece-fkmunair.com/.

Our weakness is we couldn't ensure that our participants who fill the questionnaire are honest enough and were not opening any digital searching machine while answering the questionnaire. We have counted the time needed to fill the questionnaire, and it was about more less 10 minutes. For the goodness of our research, we do hope that we can develop a more specific tool to count the participant's knowledge with an additional values to detect cheating and opening of a new tab for searching.

Another method which can be applied is by decreasing the time needed for the questionnaire fulfillment. By decreasing the time then the participants would not be able to open another tab and search for an answer.

\section{Feasibility}

\section{Study investigator and their roles}

This study is a collaboration research with all universities in Indonesia and open for all people who want to join webinar. An advisory committee will advise the PI at crucial stages on the design and implementation of the study.

\section{Study funding}

This study is funded by the Institute of Research and Community Service in Universitas Airlangga.

\section{Study Organization}

\section{Coordination}

A field research coordinator will be dedicated to ongoing supervision and monitoring of study implementation. Data collection will be monitored and evaluated regularly by the statistician. Principle investigator along with the field coordinator will also communicate regularly with the co-investigator to make sure the implementation is going well.

\section{Staff, Training, and Supervision}

In this study, we recruit speakers for webinar to give the education material for adults. Researchers will be present webinar nutrition education 4.0 once in a month with different topics and speakers.

\section{Ethical Consideration}

The study will be performed in accordance with ethical principles that have their origin in the World Health Organization-Council for International Organizations of Medical Sciences. This study has already been considered by the Health Research Ethics Committee, Universitas Airlangga, School of Medicine, Surabaya, Indonesia. Participants are recruited through the "Webinar Nutrition Education 4.0" and given verbal and written information about this research. Furthermore, participants are 
given verbal and written informed consent by the researchers to fulfill the requirement. Participants may withdraw from this study anytime without negative consequences.

\section{Acknowledgment}

This research protocol is based on the study from Universitas Airlangga. The authors are thanking to all the speakers and respondent involved in this study in Indonesia.

\section{References}

1. Gunawan IG, Suda IK, Primayana KH. Webinars as a learning resource in the midst of the COVID-19 pandemic. Purwadinata J Agama dan Budaya. 2020;4(2):127-32.

2. Djalalinia S, Qorbani M, Peykari N, Kelishadi R. Health impacts of obesity-obesity Canada. Pak J Med Sci. 2015;31(1):239-42. https://doi.org/10.12669/pjms.311.7033 PMid:25878654

3. Klassen KM, Douglass CH, Brennan L, Truby H, Lim MS. Social media use for nutrition outcomes in young adults: A mixed-methods systematic review. Int J Behav Nutr Phys Act. 2018;15(1):70. https://doi.org/10.1186/s12966-018-0696-y PMid:30041699

4. Maulana HD. Promosi Kesehatan; 2010. p. 264-71.

5. Dewi M, Aminah M. Influence of Nutrition Education towards Feeding Practice among Mom of Stunted Toddler age 6-24 years. Indones J Hum Nutr. 2016;4(1):48-58.

6. Zulaekah S. Effectiveness of Nutrition Education through Booklet toward Elementary School Pupils. J Kesehat Masy. 2013;9(1):37-43.
7. Oktaviani D. Pengaruh Media Sosialterhadap Gaya Hidup Mahasiswa IAIN Metro; 2019.

8. Putra AE. Pemanfaatan Media Sosialsebagai Sarana Dalam Membangun Kesadaran Bersedekah; 2018.

9. Amaliyah R. Hubungan Antara Kelebihan Berat Badan (Overweight) Pada Remaja Terhadap Tingkat Fleksibilitas Otot Erector Spine; 2019.

10. Pratiwi AN. Faktor-Faktor Yang Berhubungan Dengan Kejadian Overweight Pada Remaja Di SMP Methodist 1 Palembang; 2018.

11. Kementrian Kesehatan RI. Panduan Pelaksanaan Gerakan Nusantara Tekan Angka Obesitas (GENTAS); 2017. p. 32 Available from: http://www.p2ptm.kemkes.go.id/dokumen-ptm/ panduan-gentas. [Last accessed 2021 Dec 04].

12. Riskesdas. Riset Kesehatan Dasar; 2013.

13. Widyartini NP. Tinjauan Keamanan Pangan, Hygiene Sanitas dan Kandungan Gizi Makanan Tradisional di Kabupaten Tabanan. Vol. 53; 2020. p. 1689-99.

14. Zikra W, Amir A, Putra AE. Identification of Escherichia Coli on Mineral Water at Restaurant and Café in Jatiserta Jati Baru Padang City. Journal of Health Andalas. J Kesehat Andalas. 2018;7(2):212. https://doi.org/10.25077/jka.v7i2.804

15. Sapoetro M. Sikap Terhadap Pernikahan Pada Individu Dewasa Awal Yang Mengalami Perceraian Orang Tua; 2010.

16. Hootsuite and We Are Social, Digital 2020 Report: Indonesia; 2020. Available from: https://www.datareportal.com/reports/ digital-2020-indonesia [Last accessed on 2021 Jan 18].

17. Alvara. Behaviors and Preferences of Indonesian Millennial Consumers on E-Commerce Applications in 2019; 2019. Available from: https://www.alvara-strategic.com/wp-content/ uploads/2019/07/press-con-english-e-commerce-report.pdf [Last accessed on 2021 Jan 18].

18. Kemenkes RI. Riset Kesehatan Dasar Indonesia Tahun 2018. Indonesia: Kemenkes RI; 2018. Available from: https:// www.depkes.go.id/resources/download/infoterkini/materi_ rakerpop 2018/hasilriskesdas2018.pdf [Last accessed on 2021 Jan 18].

19. Cullen KW, Thompson D, Chen TA. Outcome evaluation of family eats: An eight-session web-based program promoting healthy home food environments and dietary behaviors for African American families. Health Educ Behav. 2017;44:32-40. https://doi.org/10.1177/1090198116643917 